\title{
Correction to: Metreleptin in lipodystrophy: a profile of its use
}

\section{Emma Deeks ${ }^{1}$}

Published online: 13 August 2019

(C) Springer Nature 2019

\section{Correction to: \\ Drugs \& Therapy Perspectives (2019) 35:201-208 https://doi.org/10.1007/s40267-019-00622-y}

The article Metreleptin in lipodystrophy: a profile of its use, written by Emma Deeks, was originally published Online First without open access. After publication in volume 35, issue 5, pages 201-208, Aegerion Pharmaceuticals requested that the article be Open Choice to make the article an open access publication. Post-publication open access was funded by Aegerion Pharmaceuticals. The article is forthwith distributed under the terms of the Creative Commons Attribution 4.0 International License (http://creativecommons.org/ licenses/by/4.0/), which permits use, duplication, adaptation, distribution and reproduction in any medium or format, as long as you give appropriate credit to the original author(s) and the source, provide a link to the Creative Commons license and indicate if changes were made.

The original article has been corrected.

Open Access This article is distributed under the terms of the Creative Commons Attribution 4.0 International License (http://creativecommons.org/licenses/by/4.0/), which permits unrestricted use, distribution, and reproduction in any medium, provided you give appropriate credit to the original author(s) and the source, provide a link to the Creative Commons license, and indicate if changes were made.
Emma Deeks

dtp@adis.com

1 Springer, Private Bag 65901, Mairangi Bay, Auckland 0754, New Zealand 